Prepared in cooperation with the National Park Service

\title{
Preliminary Assessment of Shallow Groundwater Chemistry near Goodell Creek, North Cascades National Park, Washington
}

Open-File Report 2019-1144 



\section{Preliminary Assessment of Shallow Groundwater Chemistry near Goodell Creek, North Cascades National Park, Washington}

By Rich W. Sheibley and James R. Foreman

Prepared in cooperation with the National Park Service

Open-File Report 2019-1144 


\section{U.S. Department of the Interior \\ David Bernhardt, Secretary}

\section{U.S. Geological Survey James F. Reilly II, Director}

U.S. Geological Survey, Reston, Virginia: 2019

For more information on the USGS-the Federal source for science about the Earth, its natural and living resources, natural hazards, and the environment-visit https://www.usgs.gov/ or call 1-888-ASK-USGS (1-888-275-8747).

For an overview of USGS information products, including maps, imagery, and publications, visit https://store.usgs.gov/.

Any use of trade, firm, or product names is for descriptive purposes only and does not imply endorsement by the U.S. Government.

Although this information product, for the most part, is in the public domain, it also may contain copyrighted materials as noted in the text. Permission to reproduce copyrighted items must be secured from the copyright owner.

Suggested citation:

Sheibley, R.W., and Foreman, J.R., 2019, Preliminary assessment of shallow groundwater chemistry near Goodell Creek, North Cascades National Park, Washington: U.S. Geological Survey Open-File Report 2019-1144, 14 p., https://doi.org/10.3133/ofr20191144.

ISSN 2331-1258 (online)] 


\section{Contents}

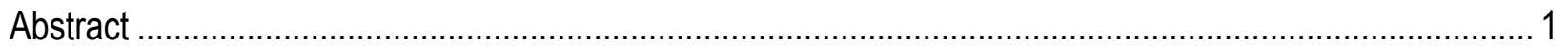

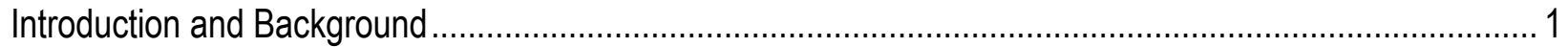

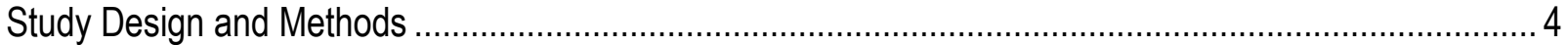

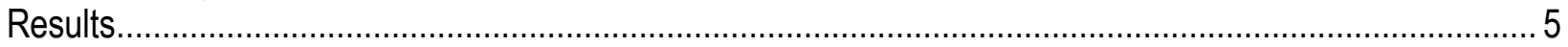

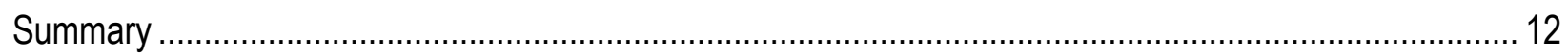

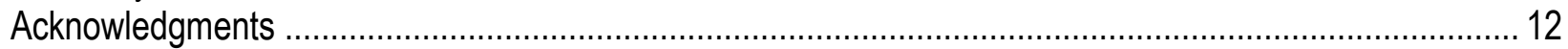

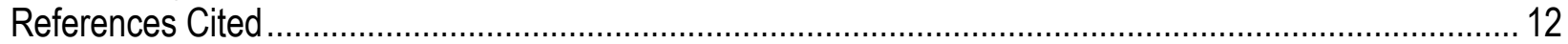

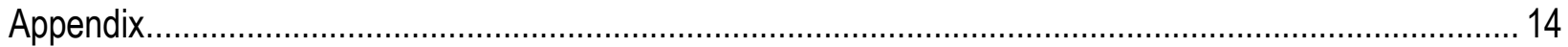

Appendix 1. Complete laboratory results for semi-volatile organic compounds in shallow groundwater near Goodell Creek, September 2017 ....................................................................................... 14

\section{Figures}

Figure 1. Map showing location of the Skagit River basin in northwestern Washington and

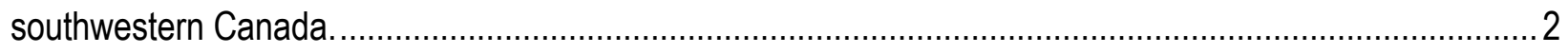

Figure 2. Map showing location of Goodell Creek and the alluvial fan near Newhalem, Washington........... 3

\section{Tables}

Table 1. Field parameters and dissolved nutrient data for shallow groundwater samples collected in

September 2017.

Table 2. Dissolved metals data for shallow groundwater samples collected in September 2017 ................ 8

Table 3. Detected concentrations of semi-volatile organics data in shallow groundwater samples collected

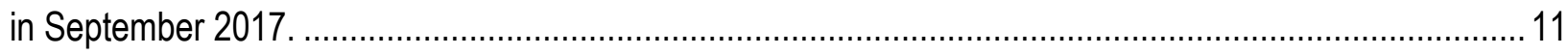

Table 4. Variability of constituents in a replicate sample for the suite of detected parameters at Well P4,

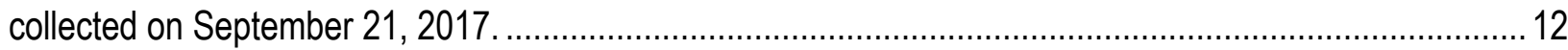




\section{Conversion Factors}

U.S. customary units to International System of Units

\begin{tabular}{|c|c|c|}
\hline Multiply & By & To obtain \\
\hline \multicolumn{3}{|c|}{ Length } \\
\hline inch (in.) & 2.54 & centimeter $(\mathrm{cm})$ \\
\hline inch (in.) & 25.4 & millimeter (mm) \\
\hline foot $(\mathrm{ft})$ & 0.3048 & meter $(\mathrm{m})$ \\
\hline mile (mi) & 1.609 & kilometer $(\mathrm{km})$ \\
\hline yard (yd) & 0.9144 & meter $(\mathrm{m})$ \\
\hline \multicolumn{3}{|c|}{ Area } \\
\hline acre & 4,047 & square meter $\left(\mathrm{m}^{2}\right)$ \\
\hline acre & 0.4047 & hectare (ha) \\
\hline acre & 0.004047 & square kilometer $\left(\mathrm{km}^{2}\right)$ \\
\hline square foot $\left(\mathrm{ft}^{2}\right)$ & 0.09290 & square meter $\left(\mathrm{m}^{2}\right)$ \\
\hline square mile $\left(\mathrm{mi}^{2}\right)$ & 259.0 & hectare (ha) \\
\hline square mile $\left(\mathrm{mi}^{2}\right)$ & 2.590 & square kilometer $\left(\mathrm{km}^{2}\right)$ \\
\hline \multicolumn{3}{|c|}{ Flow rate } \\
\hline cubic foot per second $\left(\mathrm{ft}^{3} / \mathrm{s}\right)$ & 0.02832 & cubic meter per second $\left(\mathrm{m}^{3} / \mathrm{s}\right)$ \\
\hline \multicolumn{3}{|c|}{ Mass } \\
\hline ounce, avoirdupois (oz) & 28.35 & $\operatorname{gram}(\mathrm{g})$ \\
\hline pound, avoirdupois (lb) & 0.4536 & kilogram (kg) \\
\hline \multicolumn{3}{|c|}{ Application rate } \\
\hline pound per acre per year $([\mathrm{lb} / \mathrm{acre}] / \mathrm{yr})$ & 1.121 & kilogram per hectare per year $([\mathrm{kg} / \mathrm{ha}] / \mathrm{yr})$ \\
\hline \multicolumn{3}{|c|}{ Leakance } \\
\hline foot per day per foot $([\mathrm{ft} / \mathrm{d}] / \mathrm{ft})$ & 1 & meter per day per meter $([\mathrm{m} / \mathrm{d}] / \mathrm{m})$ \\
\hline inch per year per foot $([\mathrm{in} / \mathrm{yr}] / \mathrm{ft})$ & 83.33 & millimeter per year per meter $([\mathrm{mm} / \mathrm{yr}] / \mathrm{m})$ \\
\hline
\end{tabular}

\section{Datum}

Vertical coordinate information is referenced to the [insert datum name (and abbreviation) here; for example, North American Vertical Datum of 1988 (NAVD 88)].

Horizontal coordinate information is referenced to the [insert datum name (and abbreviation) here; for example, North American Datum of 1983 (NAD 83)].

Altitude, as used in this report, refers to distance above the vertical datum.

\section{Supplemental Information}

Specific conductance is given in microsiemens per centimeter at 25 degrees Celsius $\left(\mu \mathrm{S} / \mathrm{cm}\right.$ at $\left.25^{\circ} \mathrm{C}\right)$. Concentrations of chemical constituents in water are given in either milligrams per liter $(\mathrm{mg} / \mathrm{L})$ or micrograms per liter $(\mu \mathrm{g} / \mathrm{L})$. Note to USGS users: Use of hectare (ha) as an alternative name for square hectometer $\left(\mathrm{hm}^{2}\right)$ is restricted to the measurement of small land or water areas. Use of liter $(\mathrm{L})$ as a common name for cubic decimeter $\left(\mathrm{dm}^{3}\right)$ is restricted to the measurement of liquids and gases. No prefix other than milli should be used with liter.

\section{Abbreviations}

$\begin{array}{ll}\text { USIT } & \text { Upper Skagit Indian Tribe } \\ \text { NPS } & \text { National Park Service } \\ \text { WSDOT } & \text { Washington Department of Transportation } \\ \text { SCL } & \text { Seattle City Light } \\ \text { USGS } & \text { U.S. Geological Survey }\end{array}$




\title{
Preliminary assessment of shallow groundwater chemistry near Goodell Creek, North Cascades National Park, Washington
}

\author{
By Rich W. Sheibley and James R. Foreman
}

\begin{abstract}
Goodell Creek is located within North Cascades National Park and is high-quality habitat for Chinook salmon, which are listed as threatened under the Endangered Species Act. The creation of a levee near the mouth of the creek where it enters the Skagit River has cut off the historical flood plain from the active channel. There is an effort to remove the levee along the left bank of the creek to restore this connection and preserve this high-quality habitat; however, construction debris and blasting waste from the past have been used as fill during the creation of the levee in the 1980s, and there is concern that contaminated groundwater could reach the creek if the levee is breached. As a result, the U.S. Geological Survey, in cooperation with the National Park Service, assessed near-channel shallowgroundwater chemistry to determine how levee remediation should proceed. Groundwater was sampled in late summer in 2017. Deep groundwater at that time of year limited water-quality sampling. Six samples were collected in September 2017 and analyzed for nutrients, dissolved metals, and a suite of semi-volatile organic compounds. Laboratory data were almost always reported as below the method detection limits with the exception of data from a single shallow-groundwater well. Elevated concentrations of metals detected in water samples from this well were possibly caused by the buried metal in the vicinity of the sampling location. One sample collected close to the active channel of Goodell Creek showed no signs of contamination.
\end{abstract}

\section{Introduction and Background}

Puget Sound is an estuary of national significance (Puget Sound Partnership, 2014), and the Skagit River is the largest basin by area and produces the largest stream discharge within this estuary, providing approximately 30 percent of the freshwater input into Puget Sound (fig. 1). Additionally, the upper reaches of the Skagit, including Goodell Creek, support one of the largest and most important populations of Chinook Salmon in the Puget Sound. The creek provides critical habitat for several Pacific salmon and trout species, including federally listed (https://www.fws.gov/endangered/species/usspecies.html) Steelhead, Chinook, and Bull Trout. Fortunately, Goodell Creek is located within the boundaries of North Cascades National Park (fig. 1), and most of this stream lies in a watershed that has been minimally altered by human activity (fig. 2). As such, it provides some of the best aquatic habitat in the rapidly urbanizing Puget Sound Basin. The alluvial fan of Goodell Creek extends approximately 0.6 miles upstream from the confluence with the Skagit River near Newhalem, Washington (fig. 2) and 


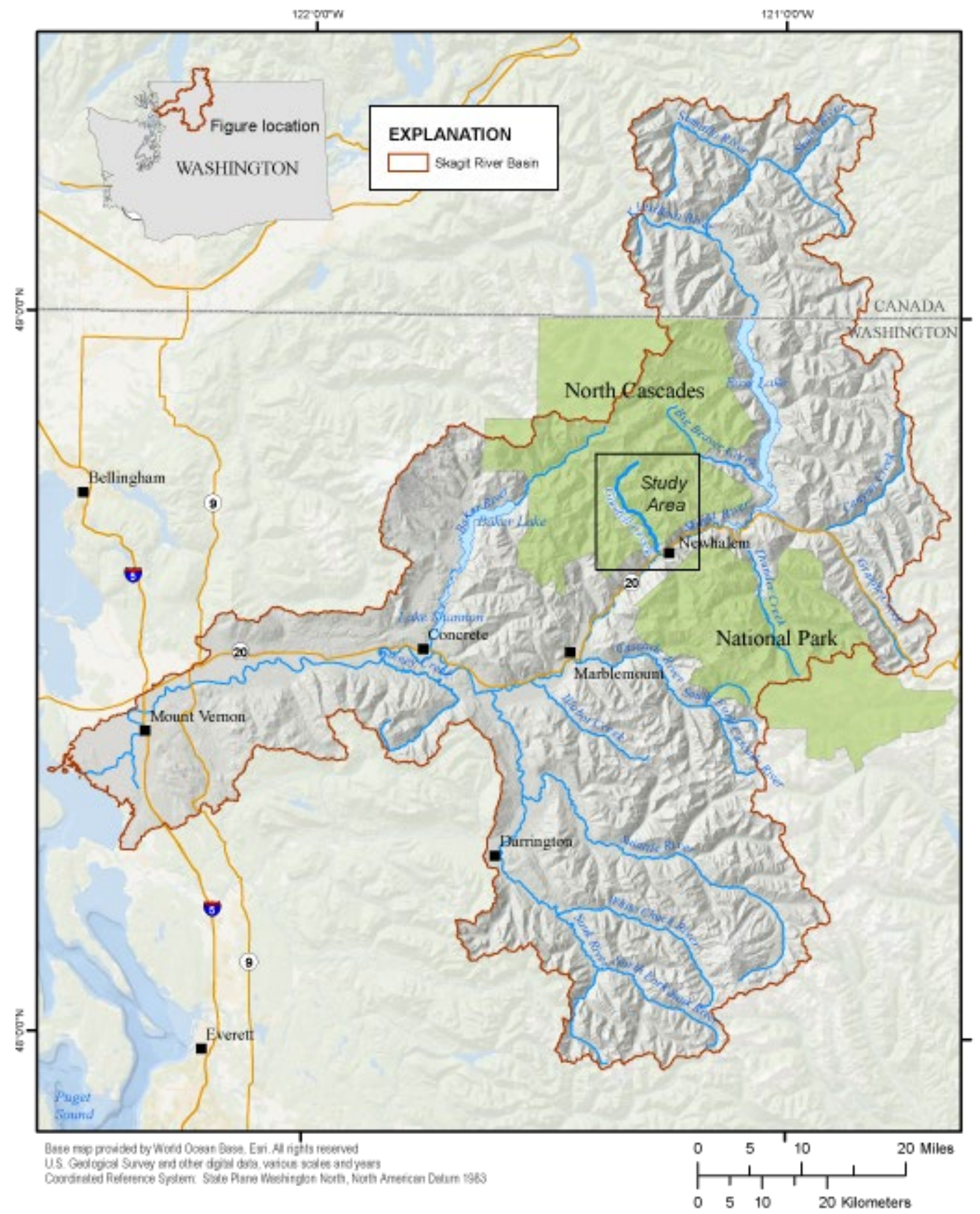

Figure 1. Map showing location of the Skagit River basin in northwestern Washington and southwestern Canada.

encompasses over 60 acres of artificially isolated flood plain and riparian habitat adjacent to the creek. The fan is composed of rich but fragmented aquatic, riparian, and flood-plain habitats and has been identified as "rare habitat" in the area and as a priority habitat for the restoration and recovery of Skagit Chinook salmon and Steelhead trout (Skagit River Systems Cooperative and Washington Department of Fish and Wildlife, 2005; Skagit Watershed Council, 2015a, 2015b). 


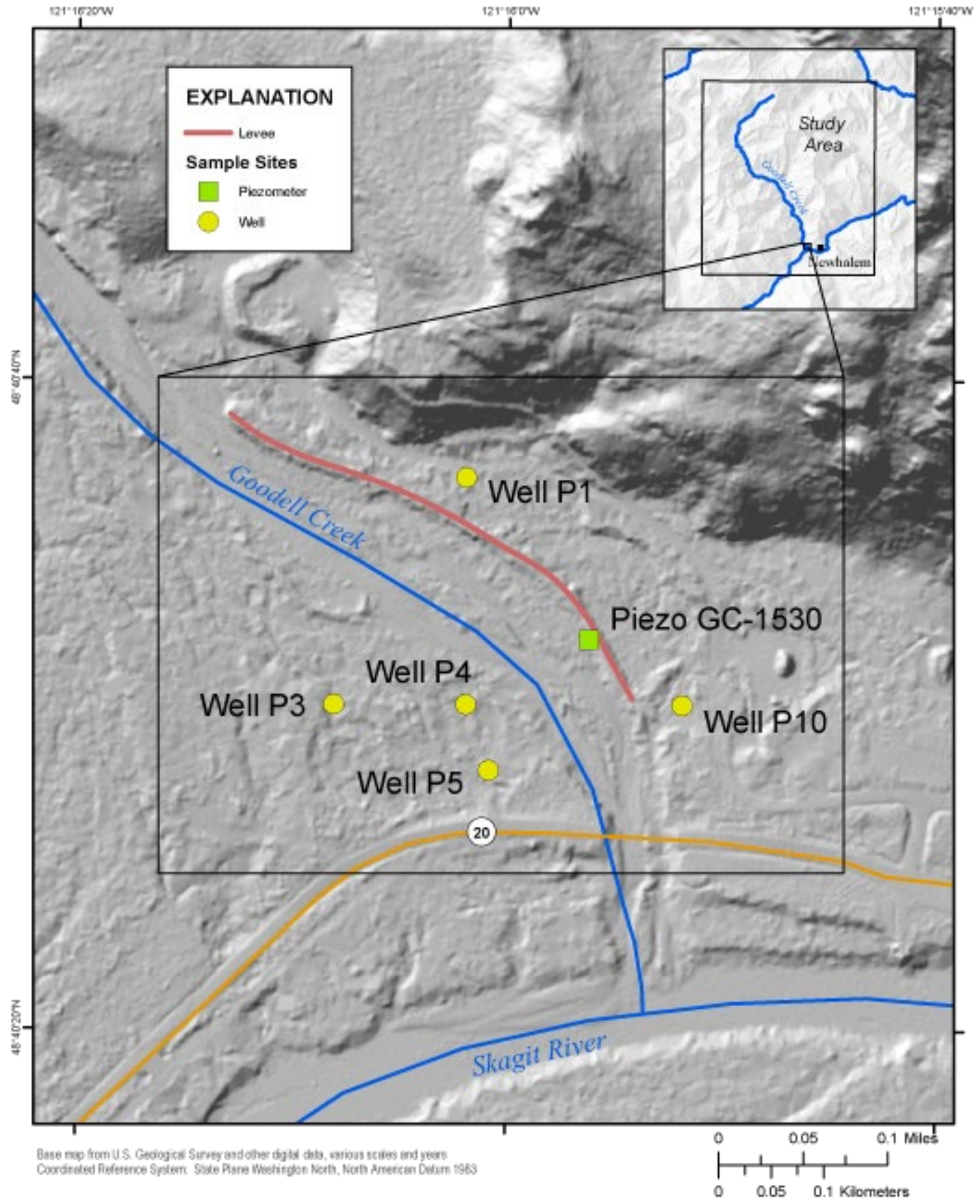

Figure 2. Map showing location of Goodell Creek and the alluvial fan near Newhalem, Washington. 
As noted previously, the lowest reach of Goodell Creek, which includes the alluvial fan, has been constrained along both banks by a variety of activities beginning at least as early as the 1920s (Herrera Environmental Consultants, 2014 and 2017). A 1500-ft long levee, which was constructed in the 1980s, still exists along the left bank of Goodell Creek on its alluvial fan (fig. 2). The upper hundred-foot section of the levee is composed of a variety of materials deposited there during construction, including metal, glass, pieces of asphalt, and concrete. The exact contents of this portion of the levee are unknown; however, it has been reported that this site is probably contaminated with arsenic and lead from sand-blasting waste (NPS, 2012). Furthermore, geophysical assessment of the levee in July 2017 by ground-penetrating radar and electromagnetic surveys indicated the presence of subsurface anomalies normally associated with buried metal (Duoos, 2017).

To restore Goodell Creek to its full natural potential and remove some of the potential risk associated with contaminated groundwater, the Upper Skagit Indian Tribe (USIT), National Park Service (NPS), Washington Department of Transportation (WSDOT), and Seattle City Light (SCL) are developing restoration plans to remove flood plain impacts, including the left bank levee, and allow the stream to reoccupy historic channels. Before considering removal or modifications, however, the NPS wants to assess potential groundwater and surface-water contamination from the materials contained in the left-bank levee. Furthermore, recent analyses of restoration alternatives suggested that there is increased risk of erosion of the levee, potentially within the next few years (Herrera Environmental Consultants, 2014 and 2017). Therefore, the NPS additionally needs to assess the potential for increased risk of contamination of the creek from erosion of the existing levee if no restoration actions were to be taken.

The goal of this project was to provide the NPS and USIT with time-critical information needed to initiate restoration of the Goodell Creek alluvial fan. Specifically, a preliminary assessment of shallow-groundwater quality around the alluvial fan was undertaken to determine the pervasiveness of contamination from the deposition of the fill material used during levee construction in this area. Whereas the suspected level of contamination associated with this project could be considered lower than in heavily developed areas in Puget Sound, this section of stream has been identified by the NPS Inventory and Monitoring Program as one of the sites at the greatest risk for water-quality impairment in the North Coast and Cascades Network of National Parks due to the presence of fill material of unknown origin in the levee along the left bank (Rawhouser and others, 2012).

\section{Study Design and Methods}

The assessment of whether groundwater contamination was affecting the lower reach of Goodell Creek was to focus on the worst-case conditions for surface-water quality during the period of lowest streamflow, from August through September. It is during this time period that pollution from discharging groundwater would be the least diluted and the potential for surface-water contamination the greatest. The original study design was to sample shallow groundwater at multiple locations along the lower creek between the active channel and the levee on the left bank (fig.2). These sample collections were intended to capture groundwater that was flowing through the levee and discharging into the lower reach of Goodell Creek. Sampling trips took place during a two-week period in September 2017. Unfortunately, the depth to groundwater during this time period was large enough to make it clear that there was no connection between the shallow groundwater adjacent to the creek and the active river channel. In some places, temporary piezometers that were installed at a depth of almost 10 feet still failed to contact groundwater. Therefore, it was not possible to collect samples in most places. As a result, the sampling plan had to be modified and was limited to a single, near-channel groundwater sample collected from the lower end of the levee (GC-1530, fig. 2) and samples collected from several existing water-level wells. These wells had been previously installed to monitor local groundwater levels for the restoration planning described above (fig. 2). 
The near-channel groundwater sample was collected by installing a temporary piezometer made from $3 / 4$-inch diameter pipe with a stainless-steel screened drivepoint (Solinst ${ }^{\circledR}$, model 615 ) to a depth of 2 to 3 feet. For the existing groundwater wells, the well caps were removed, and the depth to water was recorded prior to sampling. The sampling procedures for the temporary piezometer and groundwater wells were identical. The samples were collected by inserting acid-cleaned tubing into the piezometer or well and pumping the groundwater by using a field peristaltic pump. Field parameters (temperature, dissolved oxygen, $\mathrm{pH}$, and specific conductance) were recorded by using a field-calibrated multiparameter sonde (YSI ${ }^{\circledR}$ model $6920 \mathrm{v} 2$ ) and flow-through chamber after three well volumes had been removed, and the field-parameter readings had become stable (within 1 to 5 percent of each other).

Next, water was passed through a disc filter (Aquaprep ${ }^{\mathrm{TM}}, 0.45$-micron diameter) to be sampled for dissolved nutrients and dissolved metals. Dissolved nutrients were collected into a 125-milliliter brown polyethylene bottle after a triple rinse with filtered water and chilled before analysis. Dissolved metals were collected into a 125-milliliter clear acid-rinsed polyethylene bottle after a triple rinse with filtered water. Dissolved-metals samples were acidified to a $\mathrm{pH}$ of less than 2.0 by using 2 milliliters of 7.5-N nitric acid and chilled until analysis (Fishman, 1993). One sample for semi-volatile organics was collected at each subset of the sites into a 1-liter baked brown-glass bottle. This sample was unfiltered and chilled until analysis (Fishman and others, 1993).

Analyses for all water-quality parameters were completed at the U.S. Geological Survey (USGS) National Water Quality Lab in Denver, Colorado. Nutrients were analyzed colorimetrically by using the methods of Patton and Kryskalla (2011) and Fishman (1993); dissolved metals were analyzed by using inductively coupled plasma-mass spectrometry (Garbarino and others, 2005); and a suite of 56 semivolatile organic compounds was analyzed by gas chromatography/mass spectrometry by using the techniques of Fishman (1993). Data were reviewed and approved by USGS project personnel and are available to the public from the USGS National Water Information System (https://nwis.waterdata.usgs.gov/nwis).

\section{Results}

Water-quality data collected from the six sites (five local groundwater wells and a single nearchannel piezometer) are provided in tables 1 through 3 . One field blank and one field replicate were analyzed for each parameter to determine data quality. The concentrations measured in the field blank were below the reporting limits for all parameters, and the relative percent differences for detected parameters in the field replicate were less than ten percent for most analytes (table 4). For those parameters with greater than 20 percent relative differences, the absolute differences between the replicates were less than 1 microgram per liter $(\mu \mathrm{g} / \mathrm{L})$ except for aluminum and iron (table 4). Overall, the quality-control data indicated that the groundwater data collected for this project was of good quality.

Dissolved nutrients were low in all samples with ammonia and nitrite at or below reporting limits for all samples (table 1). Nitrate was the most frequently detected nutrient parameter, with four detections between 0.048 and 0.074 milligrams per liter $(\mathrm{mg} / \mathrm{L})$ as nitrogen $(\mathrm{N})$. Orthophosphate was below reporting limit in 4 of 6 samples and, where detected, was equal to or less than $0.01 \mathrm{mg} / \mathrm{L}$ as phosphorus $(\mathrm{P})$.

Dissolved-metals concentrations were generally low and similar in samples from all six wells, except for well P1 (table 2). At well P1, located on the eastern side of the levee (fig. 2), elevated concentrations of most of the frequently detected metals were observed and included aluminum, barium, chromium, cobalt, copper, iron, lead, lithium, manganese, nickel, vanadium, zinc, antimony, arsenic and natural uranium. Several metals were rarely detected in all samples and included beryllium, cadmium, chromium, lithium, silver, and thallium; whereas silver, boron, and selenium were not detected in any samples. At the site closest to the active channel of Goodell Creek (piezometer GC-1530), no detected 
parameter was outside the range of the other samples (table 2) except for zinc which was the lowest concentration in all samples.

Detections of semi-volatile organics were infrequent. Of the 56 parameters that were analyzed, only six were detected in four samples: 2,4,6-Trichlorophenol, Bis(2-ethylhexyl) phthalate, Di-n-butyl phthalate, Fluoranthene, Isophorone, and Naphthalene. (table 3). Of the values reported, most were estimated values from the laboratory; these estimates provide evidence that the compound is in the sample, but at a concentration level lower than the reporting limits for the long-term method (Myers, 2010). A complete data table for the semi-volatile organics, including all compounds that were not detected, is provided in appendix A. 
Table 1. Field parameters and dissolved nutrient data for shallow groundwater samples collected in September 2017.

[Abbreviations: feet, $\mathrm{ft}$; milligrams per liter, $\mathrm{mg} / \mathrm{L}$; micrograms per liter, $\mu \mathrm{g} / \mathrm{L}$; microsiemens per centimeter at 25 degrees Celsius, $\mu \mathrm{S} / \mathrm{cm}$ at $25{ }^{\circ} \mathrm{C} ;{ }^{\circ} \mathrm{C}$, degrees Celsius; N, nitrogen; P, Phosphorus; <, less than; nd, not determined]

\begin{tabular}{|c|c|c|c|c|c|c|c|c|}
\hline Station number & Field ID & $\begin{array}{l}\text { Collection } \\
\text { date }\end{array}$ & $\begin{array}{l}\text { Depth to } \\
\text { water } \\
\text { (ft) }\end{array}$ & $\begin{array}{l}\text { Collection } \\
\text { time }\end{array}$ & $\begin{array}{l}\text { Dissolved } \\
\text { oxygen, water, } \\
\text { unfiltered, } \\
\text { (mg/L) }\end{array}$ & $\begin{array}{l}\text { pH, water, } \\
\text { unfiltered, } \\
\text { field, standard } \\
\text { units }\end{array}$ & $\begin{array}{c}\text { Specific } \\
\text { conductance, } \\
\text { water, unfiltered } \\
\left(\mu \mathrm{S} / \mathrm{cm} \text { at } 25^{\circ} \mathrm{C}\right)\end{array}$ & $\begin{array}{c}\text { Temperature, } \\
\text { water } \\
\left({ }^{\circ} \mathrm{C}\right)\end{array}$ \\
\hline 484028121160101 & Well P5 & 09-19-17 & 8.55 & 1700 & 3.1 & 6.8 & 37 & 12 \\
\hline 484030121155201 & Well P10 & $09-20-17$ & 4.16 & 1740 & 0.2 & 6.4 & 23 & 11.9 \\
\hline 484030121160201 & Well P4 & $09-21-17$ & 5.00 & 1110 & 7.7 & 8 & 32 & 11.1 \\
\hline 484030121160801 & Well P3 & $09-21-17$ & 10.84 & 1150 & 7.2 & 7.6 & 22 & 11.5 \\
\hline 484032121155601 & Piezometer GC-1530 & 09-20-17 & nd & 1320 & 3.8 & 7.2 & 26 & 12.6 \\
\hline 484037121160201 & Well P1 & $09-20-17$ & 12.55 & 1615 & 7.8 & 6.8 & 23 & 11.5 \\
\hline
\end{tabular}

\begin{tabular}{|c|c|c|c|c|c|c|c|c|}
\hline Station number & Field ID & $\begin{array}{l}\text { Collection } \\
\text { date }\end{array}$ & $\begin{array}{l}\text { Depth to } \\
\text { water } \\
\text { (ft) }\end{array}$ & $\begin{array}{l}\text { Collection } \\
\text { time }\end{array}$ & $\begin{array}{c}\text { Ammonia (NH3 + } \\
\text { NH4+), water, } \\
\text { filtered } \\
\text { (mg/L as } \mathrm{N} \text { ) }\end{array}$ & $\begin{array}{l}\text { Nitrate plus } \\
\text { nitrite, water, } \\
\text { filtered } \\
\text { (mg/L as } \mathrm{N} \text { ) }\end{array}$ & $\begin{array}{l}\text { Nitrite, water, } \\
\text { filtered } \\
\text { (mg/L as N) }\end{array}$ & $\begin{array}{l}\text { Orthophosphate, } \\
\text { water, filtered } \\
\text { (mg/L as P) }\end{array}$ \\
\hline \multicolumn{9}{|l|}{4840281211601} \\
\hline $\begin{array}{c}01 \\
4840301211552\end{array}$ & Well P5 & 09-19-17 & 8.55 & 1700 & 0.051 & $<0.001$ & 0.007 & 0.007 \\
\hline $\begin{array}{l}01 \\
4840301211602\end{array}$ & Well P10 & $09-20-17$ & 4.16 & 1740 & $<0.040$ & $<0.001$ & $<0.004$ & $<0.004$ \\
\hline $\begin{array}{c}01 \\
4840301211608\end{array}$ & Well P4 & $09-21-17$ & 5.00 & 1110 & 0.069 & $<0.001$ & $<0.004$ & $<0.004$ \\
\hline $\begin{array}{c}01 \\
4840321211556\end{array}$ & Well P3 & $09-21-17$ & 10.84 & 1150 & 0.074 & $<0.001$ & 0.01 & 0.01 \\
\hline $\begin{array}{l}01 \\
4840371211602\end{array}$ & Piezometer GC-1530 & 09-20-17 & nd & 1320 & $<0.040$ & $<0.001$ & $<0.004$ & $<0.004$ \\
\hline 01 & Well P1 & $09-20-17$ & 12.55 & 1615 & 0.048 & $<0.001$ & $<0.004$ & $<0.004$ \\
\hline
\end{tabular}


Table 2. Dissolved metals data for shallow groundwater samples collected in September 2017 [feet, ft; micrograms per liter, $\mu \mathrm{g} / \mathrm{L} ;<$, less than; nd, not determined]

\begin{tabular}{|c|c|c|c|c|c|c|c|c|}
\hline Station number & Field ID & $\begin{array}{l}\text { Collection } \\
\text { date }\end{array}$ & $\begin{array}{l}\text { Collection } \\
\text { time }\end{array}$ & $\begin{array}{c}\text { Depth to } \\
\text { water } \\
\text { (ft) }\end{array}$ & $\begin{array}{c}\text { Aluminum, water, } \\
\text { filtered } \\
(\mu \mathrm{g} / \mathrm{L})\end{array}$ & \multicolumn{2}{|c|}{$\begin{array}{l}\text { Barium, water, } \\
\text { filtered } \\
(\mu \mathrm{g} / \mathrm{L})\end{array}$} & $\begin{array}{l}\text { Beryllium, water, } \\
\text { filtered, } \\
(\mu \mathrm{g} / \mathrm{L})\end{array}$ \\
\hline 484028121160101 & Well P5 & $09-19-17$ & 1700 & 8.55 & 130 & 7.88 & & 010 \\
\hline 484030121155201 & Well P10 & $09-20-17$ & 1740 & 4.16 & 28.3 & 8.65 & & 010 \\
\hline 484030121160201 & Well P4 & $09-21-17$ & 1110 & 5.00 & 39 & 11.2 & & 010 \\
\hline 484030121160801 & Well P3 & $09-21-17$ & 1150 & 10.84 & 7.1 & 10 & & 010 \\
\hline 484032121155601 & Piezometer GC-1530 & $09-20-17$ & 1320 & nd & 14.7 & 11.4 & & 010 \\
\hline 484037121160201 & Well P1 & 09-20-17 & 1615 & 12.55 & 2,790 & 31.8 & & 059 \\
\hline Station number & Field ID & $\begin{array}{l}\text { Collection } \\
\text { date }\end{array}$ & $\begin{array}{l}\text { Collection } \\
\text { time }\end{array}$ & $\begin{array}{l}\text { Depth to } \\
\text { water } \\
\text { (ft) }\end{array}$ & $\begin{array}{c}\text { Cadmium, } \\
\text { water, filtered } \\
(\mu \mathrm{g} / \mathrm{L})\end{array}$ & $\begin{array}{l}\text { Chromium, } \\
\text { water, filtered } \\
(\mu \mathrm{g} / \mathrm{L})\end{array}$ & $\begin{array}{c}\text { Cobalt, water, } \\
\text { filtered } \\
(\mu \mathrm{g} / \mathrm{L})\end{array}$ & $\begin{array}{c}\text { Copper, water, } \\
\text { filtered } \\
(\mu \mathrm{g} / \mathrm{L})\end{array}$ \\
\hline 484028121160101 & Well P5 & 09-19-17 & 1700 & 8.55 & $<0.030$ & $<0.50$ & 0.194 & 1.2 \\
\hline 484030121155201 & Well P10 & $09-20-17$ & 1740 & 4.16 & 0.052 & $<0.50$ & 0.43 & 0.58 \\
\hline 484030121160201 & Well P4 & $09-21-17$ & 1110 & 5.00 & $<0.030$ & $<0.50$ & 0.186 & 0.61 \\
\hline 484030121160801 & Well P3 & $09-21-17$ & 1150 & 10.84 & $<0.030$ & $<0.50$ & $<0.030$ & 0.26 \\
\hline 484032121155601 & Piezometer GC-1530 & $09-20-17$ & 1320 & nd & $<0.030$ & $<0.50$ & 0.248 & 0.61 \\
\hline 484037121160201 & Well P1 & $09-20-17$ & 1615 & 12.55 & 0.098 & 4.1 & 3.73 & 7.9 \\
\hline
\end{tabular}




\begin{tabular}{|c|c|c|c|c|c|c|c|c|}
\hline Station number & Field ID & $\begin{array}{l}\text { Collection } \\
\text { date }\end{array}$ & $\begin{array}{l}\text { Collection } \\
\text { time }\end{array}$ & $\begin{array}{l}\text { Depth to } \\
\text { water } \\
\text { (ft) }\end{array}$ & $\begin{array}{l}\text { Iron, water, } \\
\text { filtered } \\
(\mu \mathrm{g} / \mathrm{L})\end{array}$ & $\begin{array}{c}\text { Lead, water, } \\
\text { filtered } \\
(\mu \mathrm{g} / \mathrm{L})\end{array}$ & $\begin{array}{l}\text { Lithium, water, } \\
\text { filtered } \\
(\mu \mathrm{g} / \mathrm{L})\end{array}$ & $\begin{array}{c}\text { Manganese, } \\
\text { water, filtered } \\
(\mu \mathrm{g} / \mathrm{L})\end{array}$ \\
\hline 484028121160101 & Well P5 & 09-19-17 & 1700 & 8.55 & 121 & 0.077 & 0.47 & 1.2 \\
\hline 484030121155201 & Well P10 & $09-20-17$ & 1740 & 4.16 & 84.2 & 0.028 & $<0.15$ & 0.58 \\
\hline 484030121160201 & Well P4 & $09-21-17$ & 1110 & 5.00 & 22.8 & 0.029 & $<0.15$ & 0.61 \\
\hline 484030121160801 & Well P3 & $09-21-17$ & 1150 & 10.84 & $<10.0$ & $<0.020$ & $<0.15$ & 0.26 \\
\hline 484032121155601 & Piezometer GC-1530 & $09-20-17$ & 1320 & nd & 44.3 & 0.044 & $<0.15$ & 0.61 \\
\hline 484037121160201 & Well P1 & $09-20-17$ & 1615 & 12.55 & 1,850 & 1.33 & 1.84 & 7.9 \\
\hline Station number & Field ID & $\begin{array}{l}\text { Collection } \\
\text { date }\end{array}$ & $\begin{array}{l}\text { Collection } \\
\text { time }\end{array}$ & $\begin{array}{l}\text { Depth to } \\
\text { water } \\
\text { (ft) }\end{array}$ & $\begin{array}{c}\text { Molybdenum, } \\
\text { water, filtered } \\
(\mu \mathrm{g} / \mathrm{L})\end{array}$ & $\begin{array}{c}\text { Nickel, water, } \\
\text { filtered } \\
(\mu \mathrm{g} / \mathrm{L})\end{array}$ & $\begin{array}{l}\text { Silver, water, } \\
\text { filtered } \\
(\mu \mathrm{g} / \mathrm{L})\end{array}$ & $\begin{array}{c}\text { Strontium, } \\
\text { water, filtered } \\
(\mu \mathrm{g} / \mathrm{L})\end{array}$ \\
\hline 484028121160101 & Well P5 & $09-19-17$ & 1700 & 8.55 & 0.76 & 2.2 & $<1.00$ & 23.1 \\
\hline 484030121155201 & Well P10 & $09-20-17$ & 1740 & 4.16 & 0.159 & 0.71 & $<1.00$ & 12.6 \\
\hline 484030121160201 & Well P4 & $09-21-17$ & 1110 & 5.00 & 0.43 & 0.57 & $<1.00$ & 16.4 \\
\hline 484030121160801 & Well P3 & $09-21-17$ & 1150 & 10.84 & 0.334 & 0.75 & $<1.00$ & 16 \\
\hline 484032121155601 & Piezometer GC-1530 & $09-20-17$ & 1320 & nd & 0.391 & 0.91 & $<1.00$ & 16.3 \\
\hline 484037121160201 & Well P1 & 09-20-17 & 1615 & 12.55 & 0.499 & 6.5 & $<1.00$ & 20.1 \\
\hline
\end{tabular}




\begin{tabular}{|c|c|c|c|c|c|c|c|c|}
\hline Station number & Field ID & $\begin{array}{l}\text { Collection } \\
\text { date }\end{array}$ & $\begin{array}{l}\text { Collection } \\
\text { time }\end{array}$ & $\begin{array}{l}\text { Depth to } \\
\text { water } \\
\text { (ft) }\end{array}$ & $\begin{array}{c}\text { Thallium, } \\
\text { water, filtered } \\
(\mu \mathrm{g} / \mathrm{L})\end{array}$ & $\begin{array}{c}\text { Vanadium, } \\
\text { water, filtered } \\
(\mu \mathrm{g} / \mathrm{L})\end{array}$ & $\begin{array}{c}\text { Zinc, water, } \\
\text { filtered } \\
(\mu \mathrm{g} / \mathrm{L})\end{array}$ & $\begin{array}{c}\text { Antimony, } \\
\text { water, filtered } \\
(\mu \mathrm{g} / \mathrm{L})\end{array}$ \\
\hline 484028121160101 & Well P5 & $09-19-17$ & 1700 & 8.55 & $<0.020$ & 0.3 & 3.2 & 0.074 \\
\hline 484030121155201 & Well P10 & 09-20-17 & 1740 & 4.16 & $<0.020$ & 0.14 & 4.1 & 0.06 \\
\hline 484030121160201 & Well P4 & $09-21-17$ & 1110 & 5.00 & $<0.020$ & 0.19 & 3.2 & 0.035 \\
\hline 484030121160801 & Well P3 & $09-21-17$ & 1150 & 10.84 & $<0.020$ & 0.15 & 3.3 & $<0.030$ \\
\hline 484032121155601 & Piezometer GC-1530 & 09-20-17 & 1320 & nd & $<0.020$ & 0.28 & 3 & 0.066 \\
\hline 484037121160201 & Well P1 & 09-20-17 & 1615 & 12.55 & 0.053 & 6.3 & 19.4 & 0.149 \\
\hline Station number & Field ID & $\begin{array}{l}\text { Collection } \\
\text { date }\end{array}$ & $\begin{array}{l}\text { Collection } \\
\text { time }\end{array}$ & $\begin{array}{l}\text { Depth to } \\
\text { water } \\
\text { (ft) }\end{array}$ & $\begin{array}{c}\text { Arsenic, water, } \\
\text { filtered } \\
(\mu \mathrm{g} / \mathrm{L})\end{array}$ & $\begin{array}{l}\text { Boron, water, } \\
\text { filtered } \\
(\mu \mathrm{g} / \mathrm{L})\end{array}$ & $\begin{array}{c}\text { Selenium, } \\
\text { water, filtered } \\
(\mu \mathrm{g} / \mathrm{L})\end{array}$ & $\begin{array}{c}\text { Uranium } \\
\text { (natural), water, } \\
\text { filtered } \\
(\mu \mathrm{g} / \mathrm{L})\end{array}$ \\
\hline 484028121160101 & Well P5 & $09-19-17$ & 1700 & 8.55 & 0.27 & $<5$ & $<0.05$ & 0.023 \\
\hline 484030121155201 & Well P10 & $09-20-17$ & 1740 & 4.16 & 0.15 & $<5$ & $<0.05$ & 0.015 \\
\hline 484030121160201 & Well P4 & $09-21-17$ & 1110 & 5.00 & 0.17 & $<5$ & $<0.05$ & $<0.010$ \\
\hline 484030121160801 & Well P3 & $09-21-17$ & 1150 & 10.84 & 0.1 & $<5$ & $<0.05$ & 0.016 \\
\hline 484032121155601 & Piezometer GC-1530 & $09-20-17$ & 1320 & nd & 0.21 & $<5$ & $<0.05$ & $<0.010$ \\
\hline 484037121160201 & Well P1 & $09-20-17$ & 1615 & 12.55 & 3.6 & $<5$ & $<0.05$ & 0.284 \\
\hline
\end{tabular}


Table 3. Detected concentrations of semi-volatile organics data in shallow groundwater samples collected in September 2017.

[Abbreviations: feet, $\mathrm{ft}$; milligrams per liter, $\mathrm{mg} / \mathrm{L}$, micrograms per liter, $\mu \mathrm{g} / \mathrm{L}$; --, no sample collected; E, estimated value; <, less than; nd, not determined]

\begin{tabular}{|c|c|c|c|c|c|c|c|}
\hline Station number & Field ID & $\begin{array}{l}\text { Collection } \\
\text { date }\end{array}$ & $\begin{array}{l}\text { Depth to } \\
\text { water } \\
\text { (ft) }\end{array}$ & $\begin{array}{l}\text { Collection } \\
\text { time }\end{array}$ & $\begin{array}{c}\text { 2,4,6- } \\
\text { Trichlorophenol, } \\
\text { water, unfiltered, } \\
\text { recoverable, } \\
\text { (mg/L) }\end{array}$ & $\begin{array}{l}\text { Bis(2-ethylhexyl) } \\
\text { phthalate, water, } \\
\text { unfiltered, } \\
\text { recoverable } \\
(\mu \mathrm{g} / \mathrm{L})\end{array}$ & $\begin{array}{c}\text { Di-n-butyl } \\
\text { phthalate, water, } \\
\text { unfiltered, } \\
\text { recoverable } \\
(\mu \mathrm{g} / \mathrm{L})\end{array}$ \\
\hline 484028121160101 & Well P5 & $09-19-17$ & 8.55 & 1700 & -- & -- & -- \\
\hline 484030121155201 & Well P10 & $09-20-17$ & 4.16 & 1740 & $<0.34$ & $<7.2$ & $<2.80$ \\
\hline 484030121160201 & Well P4 & $09-21-17$ & 5.00 & 1110 & $<0.34$ & $<7.2$ & $<2.80$ \\
\hline 484030121160801 & Well P3 & $09-21-17$ & 10.84 & 1150 & -- & -- & -- \\
\hline 484032121155601 & Piezometer GC-1530 & $09-20-17$ & nd & 1320 & 0.1 & E0.5 & E0.34 \\
\hline 484037121160201 & Well P1 & $09-20-17$ & 12.55 & 1615 & $<0.34$ & E0.5 & $<2.80$ \\
\hline Station number & Field ID & $\begin{array}{l}\text { Collection } \\
\text { date }\end{array}$ & $\begin{array}{l}\text { Depth to } \\
\text { water } \\
\text { (ft) }\end{array}$ & $\begin{array}{l}\text { Collection } \\
\text { time }\end{array}$ & $\begin{array}{l}\text { Fluoranthene, } \\
\text { water, unfiltered, } \\
\text { recoverable } \\
(\mu \mathrm{g} / \mathrm{L})\end{array}$ & $\begin{array}{l}\text { Isophorone, water, } \\
\text { unfiltered, } \\
\text { recoverable } \\
(\mu \mathrm{g} / \mathrm{L})\end{array}$ & $\begin{array}{l}\text { Naphthalene, } \\
\text { water, unfiltered, } \\
\text { recoverable } \\
(\mu \mathrm{g} / \mathrm{L})\end{array}$ \\
\hline 484028121160101 & Well P5 & $09-19-17$ & 8.55 & 1700 & -- & -- & -- \\
\hline 484030121155201 & Well P10 & 09-20-17 & 4.16 & 1740 & $<0.30$ & 0.01 & E0.04 \\
\hline 484030121160201 & Well P4 & $09-21-17$ & 5.00 & 1110 & $<0.30$ & 0.06 & E0.05 \\
\hline 484030121160801 & Well P3 & $09-21-17$ & 10.84 & 1150 & -- & -- & -- \\
\hline 484032121155601 & Piezometer GC-1530 & $09-20-17$ & nd & 1320 & $<0.30$ & 0.02 & $<0.22$ \\
\hline 484037121160201 & Well P1 & $09-20-17$ & 12.55 & 1615 & $<0.30$ & $<0.26$ & E0.04 \\
\hline
\end{tabular}


Table 4. Variability of constituents in a replicate sample for the suite of detected parameters at Well P4, collected on September 21, 2017.

\begin{tabular}{lcc}
\hline \multicolumn{1}{c}{ Parameter name } & $\begin{array}{c}\text { Relative } \\
\text { percent } \\
\text { difference }\end{array}$ & $\begin{array}{c}\text { Absolute } \\
\text { difference }\end{array}$ \\
\hline Nitrate plus nitrite, water, filtered, milligrams per liter as nitrogen & 4 & 0.002 \\
Aluminum, water, filtered, micrograms per liter & 31 & 14.3 \\
Barium, water, filtered, micrograms per liter & 2 & 0.2 \\
Cobalt, water, filtered, micrograms per liter & 73 & 0.099 \\
Copper, water, filtered, micrograms per liter & 37 & 0.19 \\
Iron, water, filtered, micrograms per liter & 23 & 6 \\
Manganese, water, filtered, micrograms per liter & 5 & 0.25 \\
Molybdenum, water, filtered, micrograms per liter & 2 & 0.007 \\
Nickel, water, filtered, micrograms per liter & 2 & 0.01 \\
Strontium, water, filtered, micrograms per liter & 3 & 0.5 \\
Zinc, water, filtered, micrograms per liter & 33 & 0.9 \\
Isophorone, water, unfiltered, recoverable, micrograms per liter & 0 & 0.02 \\
\hline
\end{tabular}

\section{Summary}

In general, the groundwater quality in the six samples collected in the vicinity of the alluvial fan of Goodell Creek does not show signs of contamination; however, sampling for this preliminary study was extremely limited because the depth to groundwater along the channel was too large to be reached by sampling equipment in late summer. It is recommended that future assessment of groundwater in this area take place seasonally, especially when the groundwater table is closer to the land surface, so that more samples between the levee and active channel can be collected. The one location at the lower end of the levee where groundwater near the active channel was sampled showed no indication of elevated metals or organics. At one site, well P1, elevated levels of many metals were detected indicating that some groundwater in this area might be affected by historical construction and more recent leveebuilding activities. Well P1 is located close to the upper portion of the levee, where contamination risk is assumed to be greatest. Therefore, further investigation of groundwater flow directions either toward the creek or parallel to the creek near this well are recommended.

\section{Acknowledgments}

The USGS acknowledges the help and assistance of Ashley Rawhouser from the National Park Service and Rick Hartson from the Upper Skagit Indian Tribe, who were both instrumental in developing the project proposal and work plan for this project. In addition, we thank Christina Avolio from Herrera Environmental Consultants for background information on the geophysical surveys and general insight about the study area.

\section{References Cited}

Duoos, P.H., 2017, Goodell Creek Restoration Feasibility Project, Whatcom County, Washington, Geophysical Investigation Report, July 24, 2017, 22 p. 
Fishman, M.J., ed., 1993, Methods of analysis by the U.S. Geological Survey National Water Quality Laboratory--Determination of inorganic and organic constituents in water and fluvial sediments: U.S. Geological Survey Open-File Report 93-125, 217 p.

Garbarino, J.R., Kanagy, L.K., and Cree, M.E., 2005, Determination of elements in naturalwater, biota, sediment and soil samples using collision/reaction cell inductively coupled plasma-mass spectrometry: U.S. Geological Survey Techniques and Methods, book 5, sec. B, chap. 1,88 p.

Herrera Environmental Consultants, 2014, Conceptual Restoration Alternatives Analysis Memorandum--Goodell Creek Alluvial Fan, Tributary to the Skagit River, Newhalem, Washington: Herrera Environmental Consultants, Seattle, Washington, United States.

Herrera Environmental Consultants, 2017, Feasibility Study Report - Goodell Creek Alluvial Fan Restoration Project, Newhalem, Washington: Herrera Environmental Consultants, Seattle, Washington, United States.

Myers, D.N., 2010, Changes to the reporting convention and to data qualification approaches for selected analyte results reported by the National Water Quality Laboratory (NWQL): Office of Water Quality Technical Memorandum 2010.07, U.S. Geological Survey, Water Division.

Patton, C. J., and Kryskalla, J. R., 2011, Colorimetric determination of nitrate plus nitrite in water by enzymatic reduction, automated discrete analyzer methods: U.S. Geological Survey Techniques and Methods, book 5, chap. B8.

Puget Sound Partnership, 2014, The 2014/2015 Action Agenda for Puget Sound: Puget Sound Partnership, Tacoma, Washington, United States.

Rawhouser, A. K., Grace, L. P., Lofgren, R. A., Glesne, R. A.,Boetsch, J. R., Welch, C. A., Samora, B. A., Crain, P., and Holmes, R. E., 2012, North Coast and Cascades Network water quality monitoring protocol: Natural Resource Report NPS/NCCN/NRR—2012/571,National Park Service, Fort Collins, Colorado.

Skagit River Systems Cooperative and Washington Department of Fish and Wildlife, 2005, Skagit Chinook Recovery Plan: Skagit River Systems Cooperative, LaConner, Washington, United States.

Skagit Watershed Council, 2015a, Skagit Watershed Council Year 2015 Strategic Approach:

Skagit Watershed Council, Mount Vernon, Washington, United States.

Skagit Watershed Council, 2015b, Skagit Watershed Council 2015 Interim Steelhead Strategy: Skagit Watershed Council, Mount Vernon, Washington, United States. 


\section{Appendix}

Appendix 1 is an Excel ${ }^{\circledR}$ file and available for download at https://doi.org/10.3133/ofr20191144

Appendix 1. Complete laboratory results for semi-volatile organic compounds in shallow groundwater near Goodell Creek, September 2017 
Publishing support provided by the U.S. Geological Survey Science Publishing Network, Tacoma Publishing Service Center

For more information concerning the research in this report, contact the Director, Washington Water Science Center

U.S. Geological Survey

934 Broadway, Suite 300

Tacoma, Washington 98402

https://www.usgs.gov/centers/wa-water 
